\title{
BRIEF OVERVIEW OF THE INTERNATIONAL FLOWER MARKET, ITS STATE AND DEVELOPMENT UNDER PRESENT-DAY ECONOMIC CONDITIONS
}

\author{
V. Khodarchenko \\ National University of Life and Environmental Sciences of Ukraine
}

\begin{abstract}
The research of international flower market was conducted in this article. A big attention was paid to the main countries which are suppliers and importers of flowers and plants including their shares in the world flower production. The impact of financial crisis on this economic sector and inequality in consumption level of different countries were observed.
\end{abstract}

Key words: flower market, demand, supply, import, export.

\section{Introduction}

Flower market appeared many years ago and has its specific among other kinds of market. There are developed and developing countries that conduct this activity and for some of them it is a huge part of GDP, like countries of Latin America. Rich countries with great demand on flower products provide themselves with flowers by importing and simultaneously provide working places in developing countries. The amount of production differs strongly between countries and depends on the many factors from climatic conditions to economic possibilities.

Recently, most of the flower productions are conducted in greenhouses with high technology and protected from the weather unpredictability, but there is some external influence, like today's economic situation, that all markets are touched by and it does not make any exclusion for the flower market. That is why this question is also mentioned in this article and in need of further research.

The task of the research is to determine the main participants of the international flower market, the largest growers and importers that can influence on the world market of flowers and plants and to explore present situation on this sector of economy.

\section{Research methods}

The research is based on the methods of analysis, synthesis and summing up of information from international sources concerning flower market. Tabular and diagrammatic methods were used for representation of analytical and statistical information.

\section{Results}

The EU represents a share of ca. $10 \%$ of the world area of flowers. The Asia-Pacific region has a share of more than twothirds in the world acreage, due to China and India. China with $54 \%$ and India with $12 \%$ have a majority in the world acreage of flowers and plants. Japan, Taiwan and Thailand are other major flower producing countries in this region. The area of flowers in Africa is very small with a share $1.1 \%$. Kenya is the largest African grower. The United States and Mexico are among the most important world producers.

The share of EU production in the world production of flowers and plants is ca. 44\%. The United States, Japan, China and Canada are among the countries with the largest production of flowers and plants in the world (Graph 1).

The EU with a share of $10 \%$ in the total world area and a $44 \%$ share in the world production of flowers and plants is one of the countries with the highest flower production

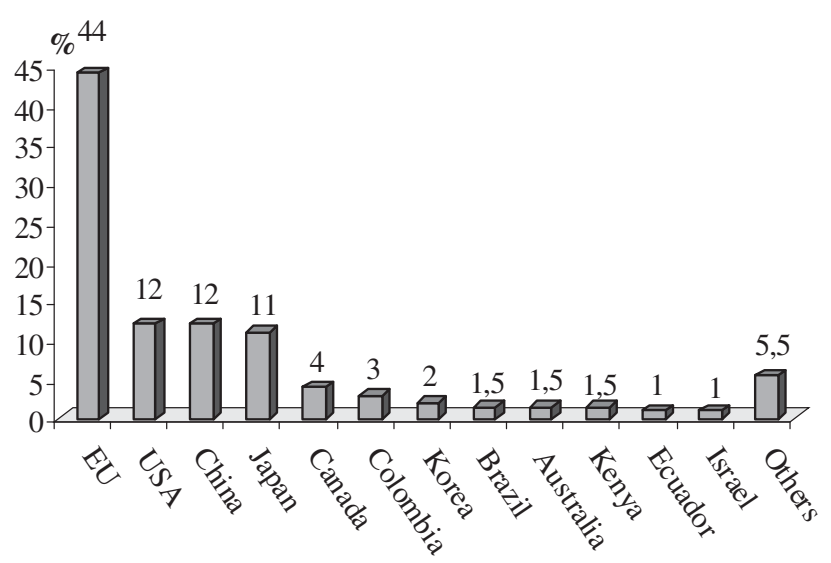

Graph 1. Flower Production Share of Countries in Value Terms

Source: AIPH/Union Fleurs: International Statistics Flowers and Plants 2009 [1] 
Table 1: Protected and open area for production of flowers and plants in comparison to yields in selected countries

\begin{tabular}{|l|c|r|r|r|r|r|}
\hline Country & $\begin{array}{c}\text { Protected } \\
\text { Area } \\
\text { hectares }\end{array}$ & $\begin{array}{c}\text { Open } \\
\text { Area } \\
\text { hectares }\end{array}$ & $\begin{array}{c}\text { Total } \\
\text { hectares } \\
\text { Production } \\
\text { millions } \\
\text { Euro }\end{array}$ & $\begin{array}{c}\text { Value of } \\
\text { Euros/ } \\
\text { hectare }\end{array}$ & $\begin{array}{c}\text { Yields } \\
\text { thousand } \\
\text { protected } \\
\text { area }\end{array}$ & $\begin{array}{c}\text { Ratio of } \\
\text { hustria }\end{array}$ \\
\hline Belgium & 618 & 1753 & 2171 & 240 & 110,548 & 19 \\
\hline Czech Republic & 129 & 1027 & 1652 & 263 & 159,200 & 38 \\
\hline Denmark & 350 & 194 & 220 & 43 & 195,454 & 59 \\
\hline France & 1909 & 3323 & 5232 & 956 & 182,721 & 36 \\
\hline Germany & 2524 & 5116 & 7640 & 1289 & 168,717 & 33 \\
\hline Hungary & 220 & 220 & 440 & 95 & 215,909 & 50 \\
\hline The Netherlands & 5047 & 2581 & 7628 & 4005 & 525,039 & 66 \\
\hline Spain & 2456 & 3684 & 6140 & 412 & 67,100 & 40 \\
\hline Sweden & 159 & 0 & 159 & 128 & 805,031 & 100 \\
\hline United Kingdom & 1043 & 5726 & 6769 & 431 & 63,672 & 15 \\
\hline China & 72701 & 224601 & 297302 & 2903 & 9,764 & 24 \\
\hline Japan & 10190 & 9869 & 20059 & 2606 & 129,916 & 51 \\
\hline United States & 6856 & 12549 & 19405 & 2992 & 154,187 & 35 \\
\hline
\end{tabular}

Source: Calculated by data of AIPH/Union Fleurs: International Statistics Flowers and Plants 2009 [1]

According to the Polish agricultural census of 2002, the greenhouse area for floriculture was 1.417 hectares in 2002. It is estimated that cut flowers account for about $65 \%$ of this area. The open area for the production of floricultural products amounted to 3.176 hectares. Around $15 \%$ of this area is used for the production of cut flowers. In accordance with an article in Floriculture International, this area is declining. Industry sources, however, indicate that the industry is very much in transition to more effective production and more cooperation. Polish production is particularly strong in spring and in summer.

Concerning shares in total acreage, Poland produces mostly Rosa (27\%), Gerbera (19\%), Dendranthema (14\%), Dianthus

intensity per hectare. Countries with a high ratio of protected production areas such as Denmark, Sweden or Netherlands achieve the highest yields per hectare. We can conclude that the production of flowers and plants under protection is mach more intensive and effective than production in open areas (Table 1).

The combined production value of EU countries according to the available data is more then $€ 19,5$ billion (97\% in old Member States and new Member States - 3\% only ). The Netherlands is by far the major producer in the EU (32\%), accounting for almost one third of total production value [12]. Production development differs strongly between countries. In some Norwest European countries like the UK, Germany and Belgium, production is declining. In the Netherlands, Italy, Spain, Belgium, Sweden and Denmark, the number of active growers is also declining. The average production per company however increases. Furthermore, East-European countries like Poland and Hungary are showing a recovery and even growth, in cut flower production [2].

In the 1970s and 1980s, Poland was sometimes called "the Holland of Eastern Europe", referring to its considerable floricultural production sector. In those times, Dianthus and Gerbera were the main products cultivated. The increasing costs of energy after the fall of communism forced many growers to stop their production in the early 1990s.

Up-to-date statististics on the Polish floricultural sector are scarce. In 2005, the Research Institute of Pomology and Floriculture Poland estimated the value of cut flower and pot plant production in Poland at $€ 501-536$ million in 2003. Approximately $€ 456$ million of the production value was ascribed to greenhouse production (cut flowers, pot plants and bulbs). Another $€ 45-70$ million was ascribed to production in open area.
(12\%), Freesia (6\%) and Anthurium (5\%) (Agricultural University of Warschaw, 2000). The total assortment of cut flowers produced in Poland is still limited, but a few crops are growing in importance like Eustoma (Lisianthus), Zantedeschia, Tulipa and Anthurium. One of the largest Anthurium farms in Europe is the 3.5 hectares big farm of JMP near Lublin. Although traditionally an important product featuring many Polish varieties, the cultivation of Gerbera is shrinking [8].

Main flower products consumption in EU is in the "old" Member States (Germany, France, and Italy). Low consumption occurs in the new Member States but it is increasing (Poland, Czech Republic). There is a stable average per capita consumption: 38 EUR per capita per year but there is significant differences between "old" Member States (45 EUR) and "new" Member States (11 EUR), Netherlands: 85 EUR per capita. As for consumption data the figures provided were calculated theoretically (Production + Imports - Exports $=$ theoretical consumption) [12].

According to the research conducted by Flower Council of Holland in 2007 Russia and Ukraine belong to countries with lowest flower consumption (Graph 2). The explanation of such situation is not only that their citizens are used to buy flowers mostly for some celebrations but also restricted financial possibilities of people.

Eurostat trade statistics illustrate that the EU is the world's leading importer of flowers, with imports amounting to $€ 3.5$ billion in 2008. In the period 2004-2008, imports increased significantly at an annual average rate of $1.9 \%$ in terms of value. In terms of volume, imports actually decreased by $2.1 \%$ on average per year. These opposite developments show that average prices of the imported flowers became higher. Germany and the UK are the leading import markets in the EU, accounting for $44 \%$ of total EU 


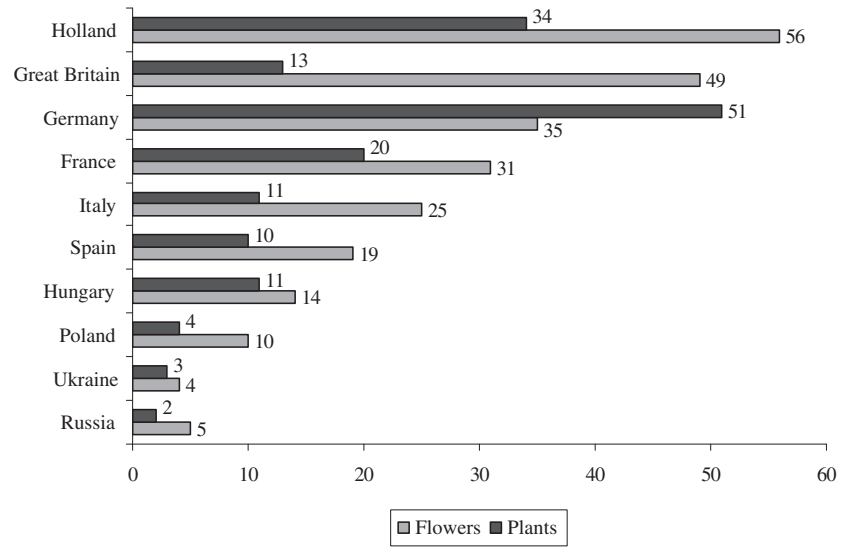

Graph 2. Per capita consumption (2207) in EUR

Source: www.flowercouncil.org/us/marketinformation/ [3]

imports (in value). In the period 2004-2008, Germany remained the largest European importer. However, imports by Germany decreased considerably since 2005 . Imports by the UK showed healthy growth from 2004 to 2008. Last year, the UK was hit hard by the global economic crisis, resulting amongst other things in a sharp drop in cut flower imports.

Only $18 \%$ of total imports was imported from outside the EU. However, this share is increasing. The Netherlands is the leading importer of products from outside the EU, accounting for more than half of these imports. A great part of Netherlands imports is re-exported to other countries, in particular Germany [11].

It was a constant trade growth in the last 10 years except for the last 2 years. Imports from third countries represent $17,6 \%$ of total deliveries (volume) and 461000 tons were imported in 2008 ( 1.5 billion EUR in terms of value $-78 \%$ cut flowers). Origin countries: Kenya - main origin for flowers and ornamental plants increased supply in the last 8 years, Costa Rica and China. EU provided 561.700 tons of export in 2008 (31\% potted plants, 16\% cut flowers and cut foliage). This volume was accounted in 1.7 billion EUR (33\% cut flowers, $29 \%$ potted plants) and delivered to Russia as a first destination (22\%), Switzerland, USA, Ukraine (6\% until now but significant growth in 2008) and other countries. USA and Japan are main destination for bulbs.

EU 27 is a net importer of cut flowers and cut foliage and net exporter of other flower products. It has a positive balance since 2002 [12].

France is the third largest market for cut flowers in the European Union, and the fourth-largest EU importer of cut flowers and foliage. Imports added up to $€ 417$ million in 2006. Major imports include roses (the most popular cut flower in France), tulips, orchids, chrysanthemums, and carnations. The main suppliers are the Netherlands (which holds a significant portion of the market about $80 \%$ of the market) followed by Italy and Spain. French consumers enjoy flowers that are brightly coloured [5].

The Netherlands is the main supplier of cut flowers to other EU member states. The dominating position of The Netherlands as a supplier to the EU is the result of both its large production and the aforementioned re-export of flowers. Besides The Netherlands, other leading cut flower suppliers to the EU contributing major shares were Kenya, Colombia, Ecuador and Israel [11].

Present situation shows that Netherlands' cut flowers market fall in turn over by $13 \%$, pot plants market increase of $3,5 \%$ in volume. There are problems with export because some destination countries encounter fluctuations in exchange rate (UK, \$-linked economies like Russia, Ukraine), even independently from economic crisis. Gas contracts will be a lot cheaper in 2010 than they were in 2009 (0.15 Eurocent per cubic meter vs. 0.44 Eurocent in 2009) but several Dutch producing companies did not survive in 2009 due to the high energy prices [12].

Recently published trade data (Eurostat) covering the year 2008 shows that The Netherlands remains the leading gateway for flowers from a number of different developing countries [10].

The major market for Kenyan flowers is also Holland with $69 \%$ of all the Kenyan flower exports through the Dutch auctions. Kenya has become the European Union's biggest source of flower imports and overtaken Israel as market leader. It has a $25 \%$ market share, beating Colombia and Israel which each have about $16 \%$ [4].

Imports from Kenya increased by $13 \%$ annually between 2004 and 2008, while imports from Ecuador increased by $20 \%$ annually during this period. Imports from Colombia and Tanzania showed significant increases as well. However, the most notable performance was that of Ethiopia. Imports from Ethiopia increased by $193 \%$ annually, with imports amounting to $€ 63$ million in 2008. Only four years before, the imports from this country were still negligible. In contrast, imports from Zimbabwe decreased by $18 \%$ annually during the review period, due to the unstable economic and political situation [10].

Analysis of recently published Eurostat data (covering trade until 2008) shows that developing countries accounted for a share of 55\% in Spanish cut flower imports in 2008. This is relatively high compared to the EU average of $24 \%$.

Between 2004 and 2008, Spanish imports from developing countries increased by $10 \%$ annually. The most important developing country suppliers are Colombia and Ecuador, together accounting for $53 \%$ of total imports. Developing countries have particularly large shares in imports of roses and carnations [7].

There is ongoing profound crisis in Spain. During last period carnations land area have been reduced by $40 \%$, roses - by $14 \%$, but prices are constant, similar to 3-4 years ago, despite increase in production costs. Incomes are decreasing, unemployment has increased, consumption has fallen and profitability has therefore fallen.

On the meeting of the advisory group on flowers and ornamental plants held in Brussels on 09/11/2009 Italian representatives of both the trade and production reported that economic crisis has strongly hit consumption in Italy in 2008-2009. Drop of 20\% in income in the sector in 2009. General signals that crisis has bottomed out but not in the 
flowers sectors (sales are not going up). Wholesalers sold a lot but not retailers. $1^{\text {st }}$ of November 2009 has been a disaster. Production is suffering a lot, partly due to structural problems (small farms, difficulties to industrialize the sector; tiny businesses in Liguria: it is going to be difficult to remain competitive in long term: very bad profitability). Additional problems are due to energy prices and financial speculation in the sector. In that respect, the use of EU funds should be carefully monitored by the Commission to ensure that they are actually used for the sector and not for speculation! Prices to producers are the number one problem worldwide (they do not cover production costs) [12].

Since 1993, the EU imports of fresh cut flowers have been dominated by Rosa. Between 2004 and 2008, imports of Rosa increased by $7.6 \%$ annually [11].

In the international market for cut flowers and foliage, the major tropical flowers (or exotics) are Orchids and Anthuriums. Other important products falling within this product group are Protea's (originally from South Africa) and of course Heliconias, Alpinia, Gingers, Strelitzias (birds of paradise) and to a lesser extent Calatheas.

Tropical flowers account for a very small portion of the international flower trade (far below 5\%). As a result, the international flower trade has structured itself almost completely according to the requirements in handling traditional flowers: low temperatures during post-harvest and transportation, the so-called cold chain.

The main international markets for tropical flowers are the European and North American markets (USA and Canada). In general, it can be said that the European market is characterized by stricter quality requirements than the North American market. The role of the Dutch (and German) flower auctions in the tropical flower trade is considerable. Most tropical flowers and foliage are directly exported to European and North American importers / importing wholesalers. Nevertheless, exporters that are able to supply consistent and large volumes of high quality should determine if selling through the auctions is a viable option as this may offer them full sales certainty. Sales via the auctions is often organized with the assistance of a local import agent who arranges eventual re-packing and distribution of the products [9].

The financial and economic crisis has already had a significant negative impact on export levels, profit margins and employment in the flower sector in developing countries.

Regional differences in trade patterns are reinforced by the crisis. Flower exporters from Latin American countries already heavily dependent on the US market before the crisis are suffering more severely as the US market faces more serious problems than the EU market. African producers known for their low prices - face pressure to cut prices even more because of the crisis. All exporters report increased rigour among European buyers in their price and margin negotiations. Moreover, more than $60 \%$ of the exporters surveyed are having difficulty obtaining export credits. More than $80 \%$ claim to be having difficulties accessing investment capital.
Within the EU, the demand for flowers has declined considerably since December 2008. Demand from the USA was already on the decline before that time. The consequence of this decline is oversupply, which in turn is leading to lower prices. Importers in the Netherlands indicate that prices have gone down by 15 to $30 \%$ since last December. Some flower species are being sold below production cost. Declining order numbers and volumes, together with decreasing prices, have caused a turnover drop among Dutch importers of 0 to $30 \%$, depending on the product range: consumer purchasing behavior is also shifting, shifting from more expensive and luxurious flowers to cheaper products.

The general expectation among respondents is that these trends will persist in the next 2 to 3 years. According to some respondents, the crisis may also have a positive effect on the sector, causing players to reorient with regard to competitive advantages, innovation and value addition [6].

\section{Conclusions}

Despite differences in flower market share of different countries, all of them are important for its development. The economics of flower oriented countries are interrelated and their cooperation in solving problems concerning flower market is important especially today. Nevertheless flower production exists and will not disappear in the future and economic crisis gives the producers to see their weak sides in order to use new opportunities.

\section{References:}

1. AIPH/Union Fleurs: International Statistics Flowers and Plants 2009

2. CBI market survey: the cut flowers and foliage market in the EU, November 2007 [http://www.cbi.eu/disclaimer]

3. http://www.flowercouncil.org/us/marketinformation/

4. http://www.kenyarep-jp.com/business/industry/f kfc e.html

5. http://www.pma.com/cig/intl/France.cfm

6. http://www.proverde.net/2009/04/the-effect-of-theinternational-financial-and-economic-crisis-on-the-flowersector-in-developing-countries/

7. http://www.proverde.net/2009/08/spain-as-an-upcomingmarket-for-flowers-from-developing-countries/

8. http://www.proverde.net/2009/09/cut-flower-production-inpoland/

9. http://www.proverde.net/2009/09/international-market-fortropical-flowers-and-foliage/

10. http://www.proverde.net/2009/09/the-netherlands-as-agateway-for-flowers-from-developing-countries/

11. http://www.proverde.net/2009/10/eu-cut-flower-imports-2008eurostat-figures/

12. Report on the meeting of the advisory group on flowers and ornamental plants held in Brussels on 09/11/2009 